\title{
Factors Affecting the Application of ERP System in the Management of Enterprises Manufacturing in Vietnam Industrial Zones
}

\author{
Master Nguyen Thanh Binh \\ Faculty of accounting and auditing \\ Industrial university of Ho Chi Minh city \\ Viet Nam
}

\begin{abstract}
Summary
Vietnam has entered a deeper stage of international integration than ever before. We have diplomatic relations with over 193 countries, with economic, trade and investment relations with many countries and territories. The integration process brings many opportunities as well as brings challenges to the extremely big competition. Vietnamese enterprises have been approaching and applying the ERP system in the process of business operation in order to improve business efficiency and competitiveness in the domestic and international markets. ERP has proven to be an effective, intuitive application that can facilitate the efficient management of production and business. ERP can be applied to all types of operations of large or small enterprises, domestic or multinational companies. Therefore, the author chose to study the topic of factors affecting the application of ERP system in the management of manufacturing enterprises in Singapore Industrial Park, Binh Duong Province, to find out the factors Influence the application of ERP system into the management of enterprises and propose solutions to apply the ERP system to the management of manufacturing enterprises in Vietnam's industrial parks in Binh Duong province. The analysis of data from SPSS 24.0 shows that the factor model influences the application of ERP systems to the management of manufacturing enterprises in Vietnam's industrial parks. Depend on 6 factors including: Support commitment of senior managers, ERP consultant qualification level, ERP project team, Business characteristics, Technology resources Information, characteristics of the ERP system.
\end{abstract}

\section{Introduction}

In the industrial age 4.0, the modern business environment with increasing competition forces businesses to seek solutions to deliver products and services to customers faster, cheaper and better than competitors. In order to reach this goal, the enterprise strives to improve its management to make the most efficient use of resources in the production and business process. Với sự trợ giúp của công nghệ thông tin, doanh nghiệp đã có công cụ hữu hiệu là các hệ thống phần mềm quản trị doanh nghiệp. Việc áp dụng các phần mềm này ngày càng trở nên phổ biến và thiết yếu với doanh nghiệp. The main reason on the author has studied the topic: "Factors affecting the application of ERP systems in the management of manufacturing enterprises in industrial parks in Vietnam" is a necessary research to find the impact relationship of elements in the ERP application process, helping businesses in Binh Duong Province have a general vision of the model to provide appropriate solutions.

\section{Theoretical basis and research methods}

\section{Theoretical basis}

Christopher P.Holland and Ben Light (1999), at Mancheser Business School, on "Model of key success factors in ERP implementation". The research topic aims to provide an answer to the question of how to implement ERP system successfully? And what are the key success factors in implementing ERP. Thereby, the research paper has analyzed the case to highlight the important issue of the impact of the characteristics of the enterprise system when the implementation process, the importance of choosing a suitable and strategic ERP The importance of changing business processes has identified the following influencing factors: Legacy system, ERP strategy, business vision, the support of senior management, project plans and schedules, customer advice, staff, software configuration, monitoring and feedback , communicate, detect problems that arise, Enterprise Resource Planning (ERP) system is an integrated comprehensive information system throughout the enterprise that automates core business processes. ERP packages of vendors like SAP, Baan, J.D. Edwards, Peoplesoft and Intentia represent more than a standard business platform, they design information plans on how the organization's business process should work. In this study, the scale and strategic importance of ERP systems are pointed out and ERP implementation issues are identified. An important success factor (CSFs) proposed framework to assist managers in developing an ERP implementation strategy. 
The framework is illustrated using two typical examples from a sample of eight companies in different industries using a random pattern theory combination until they have a common implementation model. Data collected by P.Holland and Ben by interviewing managers, IT, consultants and users is carried out for 6 months during project implementation. After analyzing the research survey results, it is shown that in addition to CSFs project management standards such as support for senior management, clear business vision, there are factors to implement ERP as factors. Inheritance, ERP strategy, business process changes, and software configuration have an important influence in the implementation process and implementation results. There are many different methods to implement ERP strategies ranging from preliminary implementation to fully functional. However, the research still has limitations such as the author based on the main success factors model when implementing ERP to analyze in two typical companies, Threads and Statco, but not yet showing the level of image. The impact of these factors on ERP implementation, as well as new factors that contribute to the successful implementation of ERP in each company.

An improved application of elements of the successful information system model. The paper aims to test the hypothesis of important factors in the successful implementation of ERP: system quality, quality of information and training positively impact the intention, attitude, behavior of people. using ERP and affecting the net benefits of enterprises of Nguyen Huu Hoang Tho Hue University of Economics published in scientific journal, Hue University, Episode 72B, No. 3, 2012 on "Impact factors to successfully deploy the resource planning system (ERP) in Vietnam "has all five factors as follows: Quality ERP system, ERP information quality, training using ERP systems, the attitude in using the system has a positive effect on the intended use behavior, Intent to use has an influence positive to organizational benefits. The study identifies the research subjects who use ERP and implement traditional sampling methods chosen in 3 representative cities, combined with online sampling through online survey website, email attachment file Electronic with 60 questionnaires is measured by the likert scale of 5 levels from highly disagree to fully released consent. After collecting valid questionnaires, the author uses statistical methods to describe and test the scale value by Cronbach alpha test combined with regression analysis and T-Value test for data analysis.

Data analysis results show that the research has contributed to a major finding that the training and training factor is more important than the system quality, information quality, and all the weak factors. Independent factors have significant impact on users' intention to use ERP in Vietnam. Therefore businesses need to invest money, time for training and training to help users grasp this management method, thereby contributing to the successful deployment of ERP systems at the enterprise. 
Table 1: Matrix rotating the EFA factor after 2 runs

\begin{tabular}{|c|c|c|c|c|c|c|c|c|c|}
\hline \multirow{2}{*}{ No. } & \multirow{2}{*}{$\begin{array}{l}\text { Observed } \\
\text { variables }\end{array}$} & \multicolumn{6}{|c|}{ Factor } & \multirow{2}{*}{$\begin{array}{l}\text { Cronbach } \\
\text { 's Alpha }\end{array}$} & \multirow[t]{2}{*}{ Factor } \\
\hline & & 1 & 2 & 3 & 4 & 5 & 6 & & \\
\hline $\begin{array}{l}1 \\
2 \\
3\end{array}$ & $\begin{array}{l}\text { DDHT2 } \\
\text { DDHT3 } \\
\text { DDHT4 } \\
\text { DDHT5 } \\
\text { DDHT1 }\end{array}$ & $\begin{array}{l}, 860 \\
, 849 \\
, 842 \\
, 733 \\
, 731\end{array}$ & & & & & & 0,865 & $\begin{array}{c}\text { Features of ERP } \\
\text { system }\end{array}$ \\
\hline $\begin{array}{c}6 \\
7 \\
8 \\
9 \\
10\end{array}$ & $\begin{array}{l}\text { TDNL2 } \\
\text { TDNL3 } \\
\text { TDNL4 } \\
\text { TDNL1 } \\
\text { TDNL5 }\end{array}$ & & $\begin{array}{l}, 876 \\
, 833 \\
, 753 \\
675 \\
637\end{array}$ & & & ,304 & & 0,836 & $\begin{array}{c}\text { Qualification of } \\
\text { consultants and ERP } \\
\text { providers }\end{array}$ \\
\hline $\begin{array}{l}11 \\
12 \\
13 \\
14\end{array}$ & $\begin{array}{l}\text { SCKHT2 } \\
\text { SCKHT1 } \\
\text { SCKHT3 } \\
\text { SCKHT5 }\end{array}$ & & & $\begin{array}{l}, 873 \\
, 858 \\
, 848 \\
, 786\end{array}$ & & & & 0,871 & $\begin{array}{c}\text { The commitment of } \\
\text { senior management } \\
\text { support }\end{array}$ \\
\hline $\begin{array}{l}15 \\
16 \\
17 \\
18 \\
19\end{array}$ & $\begin{array}{l}\text { CNTT1 } \\
\text { CNTT2 } \\
\text { CNTT3 } \\
\text { CNTT4 } \\
\text { CNTT5 }\end{array}$ & & & & $\begin{array}{l}, 839 \\
, 740 \\
, 727 \\
, 725 \\
, 681\end{array}$ & & & 0,800 & $\begin{array}{l}\text { Information } \\
\text { Technology } \\
\text { resources }\end{array}$ \\
\hline $\begin{array}{l}20 \\
21 \\
22 \\
23\end{array}$ & $\begin{array}{l}\text { DDDN4 } \\
\text { DDDN1 } \\
\text { DDDN2 } \\
\text { DDDN5 }\end{array}$ & & & & & $\begin{array}{l}, 822 \\
, 815 \\
, 791 \\
, 728\end{array}$ & & 0,839 & $\begin{array}{c}\text { Characteristics of } \\
\text { the business }\end{array}$ \\
\hline $\begin{array}{l}24 \\
25 \\
26 \\
27 \\
28\end{array}$ & $\begin{array}{l}\text { NDA4 } \\
\text { NDA5 } \\
\text { NDA1 } \\
\text { NDA2 } \\
\text { NDA3 }\end{array}$ & & & & & & $\begin{array}{l}, 730 \\
, 721 \\
, 678 \\
, 664 \\
, 630\end{array}$ & 0,719 & ERP project team \\
\hline
\end{tabular}

\section{Research Methods}

The project focuses on studying the application of ERP systems in the management of manufacturing enterprises in industrial parks in Vietnam. The data in the Dissertation was surveyed by the author between September 2016 and February 2017.Based on the above, the author chooses a sample size of 310 samples to collect data. After the survey, the total number of votes issued was 310 questionnaires, the number of votes collected was 307 votes, in the data entry and cleaning process, there were 1 invalid votes.Therefore, the official survey sample with 306, the structure of the sample is presented in the statistics table describing the research sample. Each question is measured based on a 5-point Likert scale. The research sample was collected by random method according to convenience, according to the departmental unit that was invited to collaborate during the data collection phase. The questionnaire will be issued and 
interviewed directly, the interview time after 60 minutes will be recorded. Official data collection time in October and November 2016.

\section{Results and Discussion}

\section{Research results}

Cronback's Alpha coefficients of all scales are $>$ 0.6. Coefficients Correlated with the total variable of all factors in the scale are $>0.3$. This proves that the scale used in the research model is appropriate and appropriate to analyze the next steps. Particularly SCKHT4 scale (0.871) has Cronback's Alpha coefficients that turn out to be bigger than Cronback's Alpha, so we change SCKHT4.

Particularly scale SCKHT4 (0.871) with coefficient Cronback's Alpha Analysis of EFA discovery factor 2 (Last time). We see that Barlett test results show that there are correlations between the variables in the overall $(\operatorname{sig}=0,000<0.05$ rejecting $\mathrm{H} 0$, receiving $\mathrm{H} 1$ ). At the same time, $\mathrm{KMO}$ coefficient $=0.785>0.5$, proves that factor analysis to group variables together is appropriate and data is suitable for factor analysis. The variance is $62.41 \%$ (> 50\%). The factor loading factor of all variables is satisfactory $(>0.5)$. This is also the last factor analysis and these 28 variables are considered for extracting factors in the next steps. The results show that, according to Eigenvalue criteria> 1, 6 factors are extracted and 6 factors will explain $62.41 \%$ variation of data. The method of extracting the main factor, varimax rotation to rotate the factor: turn the corner of the element to minimize the number of variables with a large coefficient at the same factor, thus enhancing the ability to explain factors. (Hoang Trong and Chu Nguyen Mong Ngoc 2008). Thus, through factor analysis, the scale of factors affecting the application of ERP systems in the management of manufacturing enterprises in industrial parks in Vietnam is 28 variables and converts into 6 factors.

\section{Analysis of linear regression models}

The regression analysis model describes the form of the relationship between the dependent variable and the independent variables, thereby helping to predict the level of the dependent variable in anticipation of the value of the independent variable. Based on the adjusted model adjusted after analyzing the exploratory factor, multiple linear regression models are expressed as follows:

$$
\mathrm{Y}=\beta 0+\beta 1 * \mathrm{SCKHT}+\beta 2 * \mathrm{TDNL}+\beta 3 * \mathrm{NDA}+\beta 4 * \mathrm{DDDN}+\beta 5 * \mathrm{CNTT}+\beta 6 * \mathrm{DDHT}+\varepsilon
$$

\section{Inside:}

- Dependent variable Y: Operational efficiency of ERP applications

- Independent variables: including 6 variables are (1) Commitment to support of senior managers, (2) Capacity of ERP consultants and suppliers, (3) ERP project team, (4) Characteristics of enterprises, (5) IT resources, (6) Characteristics of ERP systems.

Table 2: Statistical parameters in regression model

\begin{tabular}{|c|c|c|c|c|c|c|c|}
\hline \multirow{2}{*}{ Model } & \multicolumn{2}{|c|}{$\begin{array}{l}\text { The coefficient is not } \\
\text { standardized }\end{array}$} & \multirow{2}{*}{$\begin{array}{l}\text { Standardized } \\
\text { coefficient }\end{array}$} & \multirow[b]{2}{*}{$\mathbf{t}$} & \multirow[b]{2}{*}{ Sig. } & \multicolumn{2}{|c|}{ Multicollinear statistics } \\
\hline & B & $\begin{array}{l}\text { Standard } \\
\text { errors }\end{array}$ & & & & $\begin{array}{l}\text { Coefficient } \\
\text { Tolerance }\end{array}$ & VIF \\
\hline (Constant) &,- 005 &, 141 & &,- 037 & ,970 & & \\
\hline SCKHT &, 179 &, 013 & ,425 & 13,314 & ,000 & ,956 & 1,046 \\
\hline TDNL &, 171 &, 024 & ,244 & 7,011 & ,000 & ,803 & 1,246 \\
\hline NDA &, 140 & 028 & 159 & 5,040 &, 000 & ,979 & 1,022 \\
\hline DDDN &, 151 &, 024 & ,216 & 6,236 &, 000 & 809 & 1,236 \\
\hline CNTT &, 173 & 018 & ,303 & 9,610 & 000 & ,979 & 1,021 \\
\hline DDHT &, 176 & 015 &, 379 & 11,845 &, 000 & ,952 & 1,051 \\
\hline
\end{tabular}

In Table 2, when considering tstat and $t \alpha / 2$ of variables for reliability measurement, there are 6 variables: Commitment of senior managers, Capacity of consultant and ERP provider, Group ERP project, Characteristics of the enterprise, IT resources, Characteristics of the ERP system all meet the requirements of tstat $>$ t $\alpha / 2(6,306)=1,967$ (minimum is 5,040) and Sig values. showing high reliability, even <0.05 (maximum of 0.000). In addition, the coefficient VIF of the Beta coefficients is less than 10 (maximum is 1,246) and the Tolerance coefficient is equal> 0.5 (minimum is 0, 803) shows that there is no multi-linear phenomenon occurs (Hoang Trong - Mong Ngoc, 2008). 
On the other hand, the significance of the two-way verification between the independent variables and the dependent variables is satisfied (Sig. 2-tailed $=0,000<0.05$ ).

The multiple regression equation is expressed in the following form:

$\mathrm{Y}=0,425 * \mathrm{SCKHT}+0,244 * \mathrm{TDNL}+0,159 * \mathrm{NDA}+0,216 * \mathrm{DDDN}+0,303 * \mathrm{CNTT}+0,379 *$ DDHT

Table 3: Assessing the suitability of the multivariate linear regression model

\begin{tabular}{|c|c|c|c|c|c|c|c|c|c|}
\hline \multirow[b]{2}{*}{ Model } & \multirow{2}{*}{$\begin{array}{l}\text { Coefficient } \\
\text { R }\end{array}$} & \multirow{2}{*}{$\begin{array}{l}\text { Coefficient } \\
\mathbf{R}^{2}\end{array}$} & \multirow[b]{2}{*}{$\begin{array}{l}\mathbf{R} 2 \\
\text { coefficient } \\
- \\
\text { correction }\end{array}$} & \multirow[b]{2}{*}{$\begin{array}{l}\text { Standard } \\
\text { errors of } \\
\text { estimates }\end{array}$} & \multicolumn{4}{|c|}{ Statistics change } & \multirow{2}{*}{$\begin{array}{l}\text { Coefficient } \\
\text { Durbin- } \\
\text { Watson }\end{array}$} \\
\hline & & & & & $\begin{array}{l}\text { R2 } \\
\text { coefficient } \\
\text { after } \\
\text { change }\end{array}$ & $\begin{array}{l}\text { F factor } \\
\text { when } \\
\text { exchanging }\end{array}$ & $\begin{array}{l}\text { Degrees } \\
\text { of } \\
\text { freedom } \\
1\end{array}$ & $\begin{array}{l}\text { Degrees } \\
\text { of } \\
\text { freedom } \\
2\end{array}$ & \\
\hline 1 &, $842^{\mathrm{a}}$ & ,709 & ,703 & ,23846 & ,709 & 121,198 & 6 & 299 & 2,152 \\
\hline \multicolumn{10}{|c|}{ a. Independent variables: DDHT, NDA, DDDN, CNTT, SCKHT, TDNL } \\
\hline \multicolumn{10}{|c|}{ b. Dependent variable: $Y$} \\
\hline
\end{tabular}

Table 3 shows that the correlation coefficient value is $0.842>0.5$. Therefore, this is an appropriate model to use to evaluate the relationship between dependent variables and independent variables.

The determination coefficient of the adjusted R2 regression model is 0.703 . This indicates about $70.3 \%$ of the variation of factors affecting the application of ERP systems to the management of manufacturing enterprises in Vietnamese industrial parks, can be explained from the relationship. linear system between variable $\mathrm{Y}$ and independent variables.

\section{Conclusion}

Building models of factors affecting the application of ERP systems to the management of manufacturing company in industrial parks in Vietnam is based on qualitative and quantitative research that have resulted in factors such as 6 variables are (1) Commitment to support of senior managers, (2) Capacity of ERP consultant and provider, (3) ERP project team, (4) Characteristics of company, (5) IT resources,

(6) Characteristics of ERP systems directly affect the model. According to research results the commitment of senior managers is the most important in the regression model, the next order is the characteristics of the second most important ERP system, IT resources stand 3rd important position, 4th position of ERP consultant and capacity competency, Characteristics of the 5th most important enterprise and finally the ERP Project Team.

\section{Solution in ERP application in management of manufacturing enterprises in industrial zones in Vietnam}

\subsubsection{The commitment of senior management}

The senior manager must set up a person who is directly in charge of good project management and has a strong commitment to successful implementation of ERP. The support from management has greatly influenced the success of the ERP project, the senior managers are committed to learning, understanding and innovating the management process to be able to implement ERP. Dự án ERP cần phải được xác định mục tiêu chiến lược tầm nhìn phát triển dự án phải phù hợp với phát triển doanh nghiệp, cần có người từ đội ngũ lãnh đạo tham gia chỉ đạo, hỗ trợ hàng ngày. Mâu thuẫn, hay đơn giản là sự không thống nhất quan điểm có thể nảy sinh bất cứ lúc nào giữa thành viên trong đội dự án, nhất là trong giai đoạn thiết kế giải pháp và giai đoạn nghiệm thu dự án, đó là lúc cần sự dung hòa cũng như quyết đoán của lãnh đạo. The highest levels of leadership must ensure that the objectives of the project are consistent with the strategic objectives of the company. The executives must arrange personnel to participate in the project, must regularly assess and recognize success or failure early. They must motivate the project team, assist in solving problems and keep the project team active, thus supporting ERP deployment, leading to achieving value for investment resources, reduce business risks.

\subsubsection{Develop and use new information technology in the application of ERP systems to the management of enterprises}

Speeding up the process of technology modernization in Vietnam's industrial parks is one of the most important conditions to improve the quality of Vietnam Industrial Zones in general and the application of ERP systems in management of enterprises through Vietnam industrial parks in particular. Therefore, the central and urgent issue is to build a fast and stable information network to be able to convey all the necessary information to be able to transmit operational information. necessary for management and administration. Under these conditions, it may be necessary to plan appropriate steps and orientate the development of long-term information technology to accelerate the speed of 
computerization in Vietnam's industrial parks. Need to build and complete major business management programs and network connection throughout the system, Vietnam Industrial Zones need to complete software programs for ERP application in management. business logic. Along with the network-wide network connection, Vietnam Industrial Zones should work closely with relevant units in the Finance industry to build and put into operation a network of domestic tax and tax collection. import and export.

An understanding of the ERP of enterprise employees and the quality of ERP management software is assessed primarily by ensuring that the business processing requirements are met and providing information and ensuring the control of the import process. material. Thus, the control in order to meet two important objectives is Achieving and maintaining a standard application system and integrating and ensuring the handling of business operations and reliable data exchange.

In fact today there are many different suppliers and solutions with many price levels that are suitable for different types of operations and businesses, but most businesses are satisfied with ERP software. they choose.

\subsubsection{Project team capacity and ERP implementation consultant}

This factor is measured by two groups of content (1) The project group has the vision and the ability to correctly plan the outcome indicators to be achieved for the departments, the ability to review, choose the right solution due consultants recommend, support activities and timely responses to changes in employees' opposition; and (2) the consultant's knowledge of implementation of enterprise management, business sector and accounting.

The project team has an understanding of the ERP system of their units, the head of the financial accounting department is able to comprehensively understand the process processes of the ERP system and the cooperation of the staff in The group at the units in the process of operating the system will help enterprises build policies to manage information technology resources, advise and choose the right solution to meet management requirements, requirements for the business performance of the business as well as compliance with the law.

One of the biggest risks is that the project team is incapable and aware of its responsibilities and actions to select a consultant with adequate capacity and knowledge as well as to consider and choose the right solution. proposed by the consultant and policy action appropriate human resource management during this change process.

\subsubsection{Characteristics of businesses and business lines}

The results of testing the model show that the successful ERP application in addition to the external factors (Government role), the financial ability (strong) of the business, the strategic orientation of the business towards standardizing the work management and efforts of the enterprise itself: high awareness and determination of business leaders; it is necessary to correctly determine the objectives, scope and steps of implementation; Choose the right solution ... Decide on the success of the project.

The application of ERP may change the processes and management practices in the enterprise. Thus it will affect many people, greatly affecting businesses. So the leader and director must understand how ERP will change the business in terms of management and the project leader must be the highest authority in the business. Only the highest authority can make quick and correct decisions when problems occur during ERP implementation related to the management process in the enterprise. In fact, some business leaders think that ERP is purely software and assigns the administration to implement ERP projects for IT staff.

The implementation of ERP requires a lot of time with the participation of many people from many departments. So there is a need for careful preparation and planning of personnel and time. Time and manpower must be carefully calculated, balanced for ERP implementation and for other daily tasks. It is impossible to leave a job. Some units have not anticipated this, simply informing employees that there is an ERP application deployment. The staff members still see the daily work as the main thing, the job for ERP is secondary, only when done other things, only when prompted that there is a delay, only do when the consultant comes to work without any preparation. The deployment work is therefore prolonged, the results are not visible, both sides are tired, leading to the project failure.

Smart businesses choose the right ERP solution. A suitable ERP solution means being able to optimize the management and operational needs of that enterprise. But to have the right software depends on whether the business has a scientific choice? A rigorous selection process and application will help businesses make a wise decision to contribute to the success of the project.

\section{References}

Hoang Trong and Chu Mong Ngoc, 2008. Analyze research data with SPSS, Hong Duc Publishing House. 154 
Ngyen Dinh Tho, 2011. Methods of scientific research in business - design and implementation, Labor - Social Publishing House.

Nguyen Ngoc Bich, 2005. Business management identification in Vietnam. Management magazine, November 8, 2005.

Christopher P.Holland and Ben light tại Mancheser Business School (2003) about "Model of key success factors in implementing ERP".

James Y. L. Thong (1999), Information System Application Model in Small Businesses in Singapore (An Intergrated Model of Information System Adoption in Small Businesses).

Dr. Nguyen Bich Lien's Dissertation (2012) "Determining and controlling factors affecting the quality of accounting information in the environment of applying enterprise resource planning system (ERP) in Vietnamese enterprises Male".

Nguyen Huu Hoang Tho (2012) Hue University of Economics published in a scientific journal, Hue University, Episode 72B, No. 3, about "Factors affecting the successful implementation of the resource planning system. (ERP) in Vietnam ".

Vu HuuDuc, 2010. Basic problems of accounting theory. Lao Dong Publishing House.

Alter, S., 2002. The work system method for understanding information systems and information system research. Thông báo của sự Hội đối với Thông tin hệ thống, 9, 90-104.

Alter, S., 2003. 18 Reasons why IT-reliant work systems should replace "the IT artifact" as the subject matter core of the IS field. Communication of the Association for Information systems, 12, 366-395.

Alter, S. \&Sherer, A. S., 2004. A general, but the adaptable model of information system risk. Thông báo của Hội viên cho Thông tin hệ thống, 14, 1-28.

Booth, P., Matolcsy, Z. \&Wieder, B., 2000. The Enterprise Resource Planning Systems on Accounting Practice- The Austratian Experience. Australian Accounting Review 10 No.3, 4-18.

Brazel, J. F. \& Li, D., 2005. Effect of ERP System Implementation on Useful Information. Journal of Information System, October 2005.

Brazel, J. F. \& Li, D., 2008. The Effect of ERP System implementations on the Management of Earnings and Earnings release Dates. Journal of Information System Vol.22 (2), 1-21.

Eppler, M. J. \& Wittig, D, 2000. Conceptualizing Information Quality: A review of Information Quality Framework from the Last Ten Years. Proceedings of the 2000 Conference on Information Quality.

Fitz, L. \& Carroll, J. The Governance role in ERP System Implementation.

Gelinas, U. J., JR \& Dull, R. B., 2008. Accounting Information Systems,

Canada, Thomson South-Western.

Grabski, S. V., Leech, S. A. \& Bai, L. Risks and Controls in the Implementation of ERP Systems. The International Journal of Digital Accounting Research, 1 No.1, 47-69.

Hair, J. F., Anderson, R. E. \& Tatham, R. L. 1990. Multivariate Data Analysis with readings, New York Macmillan Publishing Company.

Iivari, N, 2005. the Role of Organizational Culture in Organozational Change

- Identifying a Realistic Position for prospective IS Research. European Conference on Information Systems (ECIS). 